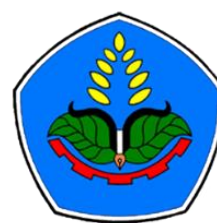

AGROPROSS

National Conference

Proceedings of Agriculture

\section{Proceedings:}

Peningkatan Produktivitas Pertanian Era Society 5.0 Pasca Pandemi

Tempat : Politeknik Negeri Jember

Tanggal : 22 Juli 2021

Publisher :

Agropross, National Conference Proceedings of Agriculture

ISBN : 978-623-94036-6-9

DOI : 10.25047 /agropross.2021.226

\title{
Uji Vigor Benih Kakao (Theobroma cacao L.) Pada Berbagai Lama Penyimpanan
}

\author{
Author(s): Anita Widhia Ningsih ${ }^{(1) *}$, Titien Fatimah ${ }^{(1)}$, Abdurrahman Salim ${ }^{(1)}$ \\ (1) Program Studi Budidaya Tanaman Perkebunan Jurusan Produksi Pertanian, Politeknik Negeri Jember \\ * Corresponding author: anitawidhia499@gmail.com
}

\begin{abstract}
Cocoa beans are recalcitrant beans or beans that cannot be stored at low temperatures. If stored at low temperatures can experience a decline in viability. Cocoa bean storage is carried out to meet the needs of planting material. To determine the storability of cocoa seeds, it is done by testing the vigor of the seeds after being stored. This research was conducted from August 2020 to October 2020 at the Jember State Polytechnic Seed Production Technology Laboratory. The experimental design used was a factorial randomized block design (RAK) consisting of 2 treatments with 4 replications. The first factor is clones, namely $K 1=$ ICCRI 03 clones: K2 = MCC 01 clones, and the second factor is Storage Time $(P)$ with 4 levels, namely $P 0=$ Seeds are directly planted (Control): $P 1=$ Seeds are stored for 5 days: $P 2=$ Seeds are stored 10 days: $P 3=$ Seeds are stored for 15 days. Parameters observed were: the number of seeds that were not damaged and not moldy, speed of germination, germination power, wet weight of sprouts, dry weight of sprouts. The results showed that the differences in clones had a very significant effect on the number of seeds that were not damaged and not moldy during storage, wet weight of sprouts, and dry weight of sprouts. The storage time treatment had a very significant effect on the number of seeds that were not damaged and not moldy during storage, the speed of germination, and the wet weight of sprouts. And the interaction between cocoa clones and storage time had a very significant effect on the number of seeds that were not damaged and not moldy during storage.
\end{abstract}

Keywords:

cocoa seed; storage time; vigor test.

\section{Kata Kunci: ABSTRAK}

biji kakao;

lama penyimpanan;

Biji kakao merupakan biji rekalsitran atau biji yang tidak dapat disimpan pada suhu rendah. Apabila disimpan pada suhu rendah dapat mengalami kemunduran viabilitasnya. Penyimpanan biji kakao dilakukan untuk memenuhi kebutuhan bahan tanam. Untuk uji vigor. mengetahui kemampuan daya simpan benih kakao dilakukan dengan menguji vigor benih benih setelah disimpan. Penelitian ini dilaksanakan pada bulan Agustus 2020 sampai dengan Oktober 2020 yang bertempat di Laboratorium Teknologi Produksi Benih Politeknik Negeri Jember. Rancangan percobaan yang digunakan adalah Rancangan Acak Kelompok (RAK) Faktorial yang terdiri atas 2 perlakuan dengan 4 ulangan. Faktor pertama adalah Klon yaitu $\mathrm{K} 1=$ Klon ICCRI $03:$ K2 = Klon MCC 01, dan faktor kedua adalah Lama Penyimpanan (P) dengan 4 taraf yaitu $\mathrm{P} 0=$ Benih langsung ditanam (Kontrol) : $\mathrm{P} 1=$ Benih disimpan 5 hari : P2 = Benih disimpan 10 hari : P3 = Benih disimpan 15 hari. Parameter yang diamati adalah : jumlah benih yang tidak rusak dan tidak berjamur, kecepatan berkecambah, daya berkecambah, berat basah kecambah, berat kering kecambah. Hasil penelitian menunjukkan bahwa perbedaan klon memberikan pengaruh sangat nyata terhadap jumlah benih yang tidak rusak dan tidak berjamur saat penyimpanan, berat basah kecambah, serta berat kering kecambah. Perlakuan lama penyimpanan memiliki pengaruh berbeda sangat nyata terhadap jumlah benih yang tidak rusak dan tidak berjamur saat penyimpanan, kecepatan berkecambah, serta berat basah kecambah. Serta interaksi antara klon kakao dan lama penyimpanan memiliki pengaruh berbeda sangat nyata terhadap jumlah benih yang tidak rusak dan tidak berjamur saat penyimpanan. 


\section{PENDAHULUAN}

Tanaman kakao (Theobroma cacao L.) bukanlah termasuk tanaman asli dari Indonesia, tetapi merupakan tanaman tropis asli Amerika Selatan. Tanaman kakao tidak hanya dibudidayakan di Indonesia saja, namun juga sudah ditanam di berbagai kawasan tropis. Kakao termasuk salah satu golongan komoditi unggul perkebunan yang berperan cukup penting didalam perekonomian nasional Indonesia. Perkembangan pada perkebunan ditentukan oleh keberadaan bahan tanamnya, begitupun dengan perkebunan kakao. Perbanyakan tanaman kakao dapat dilakukan dengan dua cara yaitu perbanyakan generatif dengan menggunakan biji serta perbanyakan vegetatif dengan cara stek, grafting, ataupun okulasi.

Biji kakao adalah biji keras atau biji yang tidak dapat disimpan pada suhu rendah. Jika disimpan pada suhu rendah, tingkat kelangsungan hidup akan menurun. Vigor adalah kemampuan benih untuk berkecambah. Jika viabilitas benih buruk maka akan mempengaruhi daya berkecambah. Menurut Walters et al. (2001), benih rekalsitran adalah benih yang tidak dapat disimpan dalam jangka waktu yang. lama dan pada suhu dingin, serta kadar air di bawah kadar air kritis. Contoh benih rekalsitran adalah benih nangka (Artocarpus heterophyllus), benih meranti (Shorea selanica), benih gaharu (Aquilaria malaccensis), benih damar (Agathis sp.), benih kemenyan (Styrax benzoin), benih mimba (Azadirachta indica), benih bakau (Rhizophora apiculata), dan benih nyamplung (Calophyllum inophyllum).

Benih rekalsitran dapat dicirikan oleh ukuran yang relatif lebih besar dibandingkan dengan benih ortodoks, memiliki kadar air 30-70\% mudah terkontaminasi mikroorganisme, tidak toleran terhadap suhu rendah dan beku (chilling and freezing injury), periode penyimpanan yang singkat, mudah berkecambah di penyimpanan dan peka terhdap penurunan kadar air.

Penyimpanan biji kakao sendiri dilakukan untuk memenuhi kebutuhan bahan tanam, karena tanaman kakao hanya berbuah satu kali dalam setahun. Selain itu, penyimpanan dilakukan dengan tujuan untuk memudahkan dalam transportasi pengiriman yang juga memerlukan waktu beberapa hari untuk perjalanan sampai ke lokasi pembibitan.

Pada penyimpanan yang dilakukan dengan cara konvensional, menggunakan media simpan serbuk gergaji atapun arang sekam merupakan metode yang kurang menguntungkan karena kondisi lingkungan di sekitar benih akan menjadi lebih lembab sehingga mendorong pertumbuhan jamur. Tidak hanya itu, penyimpanan secara konvensional berpotensi tinggi membuat benih berkecambah pada media simpan. Menurut Yazid (2020), viabilitas benih karet mulai mengalami penurunan pada penyimpanan 10 hari menggunakan media simpan berupa serbuk gergaji.

\section{BAHAN DAN METODE}

Penelitian ini dilaksanakan di Laboratorium Teknologi Produksi Benih Politeknik Negeri Jember pada bulan Agustus 2020 sampai Oktober 2020. Bahan yang digunakan dalam penelitian ini yaitu dua klon benih kakao (ICCRI 03 dan MCC 01), pasir (media tanam), fungisida, air, osmotikum dengan merk dagang PEG6000, kertas merang, kertas label. Alat yang digunakan yaitu ruang germinator, plastik pembungkus, gelas ukur, timbangan analitik, tray penyimpanan, kantong kecambah, desikator, penggaris, kamera, bak perkecambahan, bak plastik, peniris benih, alat tulis, moisture tester, thermohygrometer, oven.

Penelitian ini menggunakan Rancangan Acak Kelompok Faktorial yang terdiri dari 2 faktor yaitu klon dan lama penyimpanan yang diulang sebanyak 4 
kali. Setiap satu percobaan menggunakan sampel 30 benih kakao. Faktor pertama adalah media penyimpanan benih yang terdiri atas dua taraf yaitu:

K1 : Klon ICCRI 03

K2 : Klon MCC 01

Faktor kedua adalah lama penyimpanan benih yang terdiri atas tiga taraf dan satu kontrol, yaitu:

P0 : kontrol (langsung ditanam)
P1 : Benih disimpan selama 5 hari

P2 : Benih disimpan selama 10 hari

P3 : Benih disimpan selama 15 hari

\section{HASIL DAN PEMBAHASAN}

Dari hasil penelitian Uji Vigor Benih Kakao (Theobroma cacao L.) pada Berbagai Lama Penyimpanan, maka diperoleh hasil beberapa parameter pengamatan yang telah dilakukan.

Tabel 1 Rangkuman Uji Anova Uji Vigor dan Viabiltas Benih Klon Kakao (Theobroma cacao L) Pada Berbagai Lama Penyimpanan

\begin{tabular}{llccc}
\hline \multirow{2}{*}{ No } & \multicolumn{2}{c}{ Parameter } & \multicolumn{3}{c}{ Hasil Anova } \\
\cline { 3 - 5 } & & $\mathrm{K}$ & $\mathrm{P}$ & $\mathrm{K}$ x P \\
\hline 1 & Jumlah Benih yang Tidak Rusak dan Berjamur & $19,89^{* *}$ & $44,76^{* *}$ & $8,11^{* *}$ \\
2 & Kecepatan Berkecambah (etmal) & $0,42^{\mathrm{NS}}$ & $7,87^{* *}$ & $1,22^{\mathrm{NS}}$ \\
3 & Daya Berkecambah (\%) & $0,04^{\mathrm{NS}}$ & $1,07^{\mathrm{NS}}$ & $1,18^{\mathrm{NS}}$ \\
4 & Berat Basah Kecambah (gr) & $200,03^{* *}$ & $6,81^{* *}$ & $1,17^{\mathrm{NS}}$ \\
5 & Berat Kering Kecambah (gr) & $379,32^{* *}$ & $0,51^{\mathrm{NS}}$ & $0,3^{\mathrm{NS}}$ \\
\hline
\end{tabular}

\begin{tabular}{clcc}
\hline \multirow{2}{*}{ No } & \multicolumn{1}{c}{ Parameter } & \multicolumn{2}{c}{ Uji F Tabel } \\
& \multicolumn{1}{c}{$5 \%$} & $1 \%$ \\
\hline 1 & Jumlah Benih yang Tidak Rusak dan Berjamur & K 4,32 & K 8,02 \\
2 & Kecepatan Berkecambah (etmal) & & \\
3 & Daya Berkecambah (\%) & P 3,07 & P 4,87 \\
4 & Berat Basah Kecambah (gr) & KxP 3,07 & KxP 4,87 \\
5 & Berat Kering Kecambah (gr)
\end{tabular}

Keterangan :

$\mathrm{K}=\mathrm{Klon}$

$\mathrm{P}=$ Lama Penyimpanan

$\mathrm{K}$ x P = Interaksi Klon dan Lama Penyimpanan

NS $=$ Non Significant $($ Berbeda Tidak Nyata)

$*$ = Berbeda Nyata

** = Berbeda Sangat Nyata

\section{Benih yang Tidak Rusak dan Tidak Berjamur Di Penyimpanan}

Kerusakan benih yang terjadi disini yaitu benih rusak disebabkan benih berair dan lembek. Benih kakao klon ICCRI 03 maupun klon MCC 01 memiliki tingkat kerusakan benih yang sama. Semakin lama benih disimpan maka akan menurunkan kualitas benih kakao. Benih yang rusak muncul pada penyimpanan benih 10-15 hari. Kerusakan benih dapat terjadi akibat respirasi benih selama di penyimpanan. Hal ini sesuai dengan pernyataan Copeland L.O and M.B. Mc Donald (2001) dan Walters et al. (2001), bahwa Proses respirasi benih yang sangat tinggi membuat benih memiliki metabolisme yang cepat dan panas yang dihasilkan membuat benih lembab, sehinga benih dengan mudah terkontaminasi mikroba dan mengalami kerusakan.Parimala et al. (2013), berpendapat bahwa benih yang 
sehat dapat disimpan untuk jangka waktu yang lebih lama apabila dibandingkan dengan benih yang rusak.

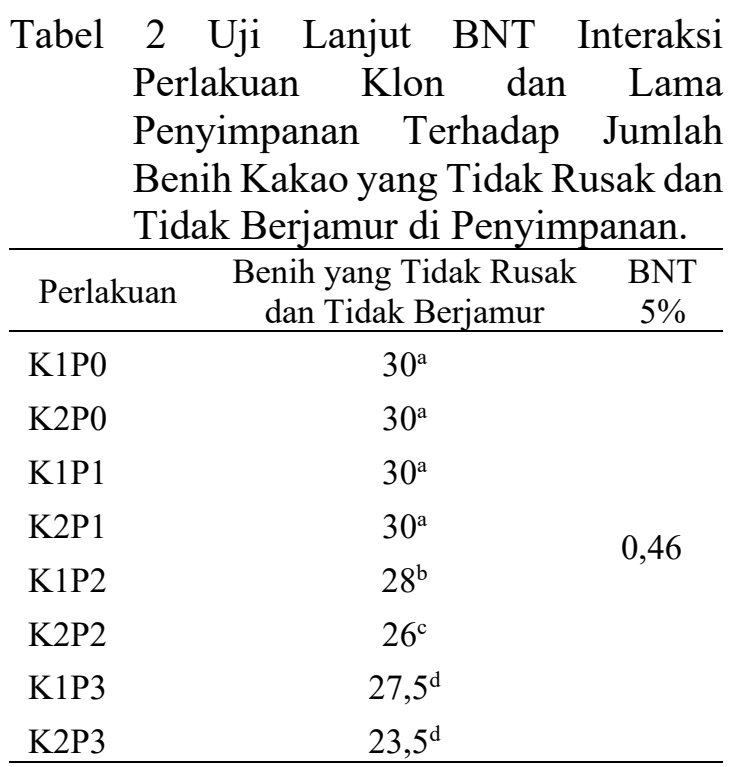

Jumlah benih yang terserang jamur selama penyimpanan cenderung mengalami peningkatan, semakin lama benih disimpan maka serangan jamur nya lebih tinggi. Benih kakao dengan klon MCC 01 lebih tinggi serangan jamurnya daripada benih kakao dengan klon ICCRI 03. Serangan jamur pada periode penyimpanan diduga berasal dari jamur yang terbawa oleh benih ketika di kebun karena apabila dari tingginya kadar air maka kadar air benih klon ICCRI 03 lebih tinggi dari klon MCC 01.

Sesuai dengan pernyataan Farida et al. (2017), bahwa jamur yang terdapat pada benih selama penyimpanan tidak selalu disebabkan metabolisme jamur selama penyimpanan, akan tetapi jamur tersebut terbawa benih ketika masih di pohon atau pengolahan pasca panen. Kualitas benih dapat sangat dipengaruhi oleh berbagai kondisi lingkungan dari tahap kematangan fisiologis saat panen. Faktor-faktor seperti kesehatan tanah, ketersediaan nutrisi tanaman, kekurangan gizi selama pertumbuhan tanaman, kerusakan karena hama dan penyakit dapat mempengaruhi kualitas benih sebelum dipanen (Parimala et al., 2013).

\section{Kecepatan Berkecambah (Etmal)}

Tabel 3 Uji Lanjut BNT Perlakuan Lama Penyimpanan Terhadap Kecepatan Berkecambah Benih Kakao Sampai Umur 14 HSS.

\begin{tabular}{ccc}
\hline $\begin{array}{c}\text { Perlaku } \\
\text { an }\end{array}$ & $\begin{array}{c}\text { Kecepatan Berkecambah } \\
\text { (etmal) }\end{array}$ & $\begin{array}{c}\text { BNT } \\
5 \%\end{array}$ \\
\hline P0 & $49,20 \mathrm{a}$ & \\
P1 & $44,96 \mathrm{~b}$ & \\
P2 & $45,72 \mathrm{~b}$ & 2,61 \\
P3 & $36,61 \mathrm{c}$ & \\
\hline
\end{tabular}

Perlakuan P0 memiliki kecepatan berkecambah tertinggi dengan rata-rata 49,20 etmal, kemudian disusul P1 dan P2 karena berbeda tidak nyata dengan ratarata 44,96 etmal dan 45,72 etmal, dan kecepatan berkecambah terendah diperoleh pada perlakuan P3 dengan rata-rata 36,61 etmal.

Benih mampu berkecambah dengan cepat dan berbeda sangat nyata pada perlakuan kontrol, kemudian menurun setelah disimpan 5 hari dan meningkat namun tidak berbeda nyata pada penyimpanan 10 hari. Setelah itu benih kakao mengalami penurunan kecepatan daya berkecambah cukup tinggi dan berbeda sangat nyata pada penyimpanan 15 hari. Penurunan kecapatan berkecambah pada ini disebabkan karena semakin lama benih disimpan maka vigor nya akan rendah.

Menurut Sadjad (1994), vigor benih tinggi memiliki kekuatan tumbuh yang tinggi serta daya simpan yang tinggi. Kecepatan tumbuh merupakan salahsatu tolok ukur dari parameter vigor kekuatan tumbuh. Kecepatan tumbuh memiliki hubungan erat dengan vigor benih, benih yang kecepatan tumbuhnya tinggi akan menghasilkan tanaman yang cenderung lebih tahan terhadap keadaan yang suboptimum (Farida et al. 2017) 
Kondisi fisiologis dari benih yang dapat menyebabkan rendahnya vigor adalah "immaturity" atau kurang masaknya benih pada waktupanen dan juga kemunduran benih selama penyimpanan (Heydecker, 1972). Penurunan kecepatan berkecambah sejalan dengan waktu penyimpanan. Semakin lama benih disimpan menyebabkan kecepatan berkecambah semakin rendah (Hartawan dan Nengsih, 2012).

\section{Daya Berkecambah (\%)}

Daya kecambah merupakan salah satu pengujian yang digunakan untuk mengetahui vigor benih, dimana viabilitas benih itu sendiri mencangkup vigor serta daya kecambah benih. Dari hasil analisa sidik ragam menunjukkan bahwa perlakuan klon maupun lama penyimpanan tidak berbeda nyata, serta tidak terjadi interaksi antara perlakuan klon dengan lama penyimpanan.

Daya kecambah merupakan salah satu komponen untuk mengetahui atau melihat viabilitas benih. Seperti yang telah dijelaskan oleh Copeland L.O and M.B. Mc Donald (2001), bahwa viabilitas benih dapat diukur dengan tolokukur pengamatan daya berkecambah. Perkecambahan benih merupakan kemunculan dan perkembangan struktur penting dari embrio benih serta kemampuan benih untuk berkembang menjadi tanaman normal.

Menurut Rahardjo (2012) diduga proses metabolisme pernafasan benih kakao selama penyimpanan belum menimbulkan pemakaian cadangan makanan sehingga sumber energi benih masih mencukupi untuk pertumbuhan bibit kakao. Daya berkecambah benih yang rendah dapat disebabkan olehbenik karena mengalami gangguan fisik maupun fisiologis (Mudiana, 2007). Penurunan mutu fisiologis benih kakao setelah penyimpanan benih selama empat minggu terlihat pada rendahnya daya berkecambah dan kecepatan tumbuh (Baharudin et al., 2010).

Peran PEG 6000 dalam menekan respirasi benih dalam penyimpanan memperkecel hilangnya cadangan makanan sehingga pada saat benih dikecambahkan cadangan makanan di dalam benih masih banyak tersedia yang berkorelasi dengan kemampuan benih untuk dapat tumbuh dengan baik (Putra et al., 2013) Pemberian PEG 30\% menghasilkan rekapitulasi persentase daya berkecambah setelah penyimpanan yang lebih tinggi dibanding dengan perlakuan lainnya (Husni et al., 2014).

\section{Berat Basah Kecambah}

Tabel 4 Uji Lanjut BNT Perlakuan Klon Terhadap Berat Basah Kecambah Kakao per Tanaman Umur 14 HSS.

\begin{tabular}{ccc}
\hline Perlakuan & Berat Basah (gr) & BNT 5\% \\
\hline K1 (ICCRI 03) & $2,03^{\mathrm{b}}$ & 0,11 \\
K2 (MCC 01) & $3,2^{\mathrm{a}}$ & \\
\hline
\end{tabular}

Tabel 5 Uji Lanjut BNT Perlakuan Lama Penyimpanan Terhadap Berat Basah Kecambah Kakao per Tanaman Umur 14 HSS.

\begin{tabular}{lcc}
\hline \multicolumn{1}{c}{ Perlakuan } & Berat Basah (gr) & BNT 5\% \\
\hline P0 (Kontrol) & $2,68^{\mathrm{b}}$ & \\
P1 (5 Hari) & $2,44^{\mathrm{c}}$ & 0,11 \\
P2 (10 Hari) & $2,45^{\mathrm{c}}$ & \\
P3 (15 Hari) & $2,90^{\mathrm{a}}$ & \\
\hline \multicolumn{4}{r}{ Dari } & data & peubah & yang
\end{tabular}
diperoleh dapat dilihat bahwa perlakuan klon dan lama penyimpanan berpengaruh nyata terhadap berat basah kecambah kakao. Perbedaan nyata ini dapat dipengaruhi oleh faktor kondisi bibit itu sendiri dan juga kemampuan bibit dalam menyerap kandungan air pada media nya. Dari bentuk fisik benihnya, benih kakao dengan klon MCC 01 memiliki ukuran lebih besar daripada benih kakao dengan klon ICCRI 03. Sesuai dengan pernyataan Sutopo (2002) bahwa benih yang berukuran besar dan berat mengandung 
cadangan makanan lebih banyak dibandingkan benih yang berukuran kecildan diduga bahwa memiliki ukuran mebrio yang cukup besar.

\section{Berat Kering Kecambah}

Tabel 6 Uji Lanjut BNT Perlakuan Beda Klon Terhadap Berat Kering Kecambah Kakao per Tanaman Umur 14 HSS.

\begin{tabular}{ccc}
\hline Perlakuan & Berat Kering (gr) & BNT 5\% \\
\hline K1 (ICRRI 03) & $0,87^{\mathrm{b}}$ & \multirow{2}{*}{0,04} \\
K2 (MCC 01) & $1,45^{\mathrm{a}}$ & \\
\hline
\end{tabular}

Berat kering kecambah merupakan berat/bobot bibit setelah kehilangan kadar airnya dengan cara pengovenan. Dari data peubah yang diperoleh dapat dilihat bahwa klon berpengaruh nyata terhadap berat kering benih kakao. Ini sesuai yang telah dijelaskan oleh Sutopo (2002), bahwa perbedaan ukuran dan berat benih mempengaruhi jumlah cadangan makanan yang terkandung didalam benih.

Sesuai dengan berat basahya ratarata berat kering kecambahnya pun tidak jauh berbeda. Rata-rata berat kering bibit kakao dengan klon ICCRI 03 lebih rendah dibandingkan dengan bibit kakao klon MCC 01. Rata-rata berat kering bibit kakao pada kedua klon ini selaras dengan ratarata berat basahnya, maksudnya bibit yang memiliki berat basah tertinggi merupakan bibit yang memiliki berat kering tertinggi pula, begitu juga bibit yang memiliki berat basah terendah merupakan bibit yang memiliki berat kering terendah pula.

Prawiranata et al. (1981), menerangkan bahwa, peningkatan berat kering tanaman menunjukkan pertumbuhan vegetatif berjalan baik. Sitompul and Guritno (1995) juga berpendapat bahwa, berat kering tanaman lebih menunjukan status pertumbuhan tanaman.

\section{KESIMPULAN}

1. Perbedaan klon kakao memiliki pengaruh berbeda sangat nyata terhadap jumlah benih yang tidak rusak dan tidak berjamur saat penyimpanan, berat basah kecambah, serta berat kering kecambah, tetapi memiliki pengaruh berbeda tidak nyata terhadap kecepatan berkecambah dan daya berkecambah benih kakao. Klon terbaik pada uji vigor benih kakao yaitu klon MCC 01 (K1).

2. Lama penyimpanan memiliki pengaruh berbeda sangat nyata terhadap jumlah benih yang tidak rusak dan tidak berjamur saat penyimpanan, kecepatan berkecambah, serta berat basah kecambah, tetapi mempunyai pengaruh berbeda tidak nyata terhadap perlakuan daya berkecambah dan berat kering benih kakao. Lama penyimpanan terhadap kecepatan berkecambah terbaik yaitu pada kontrol (P0), serta berat basah terbaik terdapat pada penyimpanan benih selama 15 hari (P3).

3. Interaksi antara klon kakao dan lama penyimpanan memiliki pengaruh berbeda sangat nyata terhadap jumlah benih yang tidak rusak dan tidak berjamur saat penyimpanan, tetapi tidak memiliki pengaruh yang nyata pada pengamatan kecepatan berkecambah, daya berkecambah, berat basah, dan berat kering kecambah kakao. Perlakuan K1P0, K2P0, K1P1, dan K2P1 merupakan jumlah benih tidak rusak dan benih tidak berjamur paling banyak dibanding dengan perlakuan lainnya.

\section{DAFTAR PUSTAKA}

Baharudin, Ilyas, S., Suhartanto, M.R. And Purwantara, A., 2010. Pengaruh Lama Penyimpanan Dan Perlakuan Benih Terhadap Peningkatan Vigor 
Benih Kakao Hibrida. Jurnal Pengkajian Dan Pengembangan Teknologi Pertanian, 13(1), pp.7384.

Copeland L.O And M.B. Mc Donald, 2001. Seed Science And Technology 4 Th., Kluwer Academic, London.

Farida, Z.N.L.E., Saptadi, D. And Respatijarti, 2017. Uji Vigor Dan Viabilitas Benih Dua Klon Karet ( Hevea Brasiliensis Muell Arg .) Pada Beberapa Periode Penyimpanan Seed Vigor And Vablity Test Of Two Clones Of Rubber ( Hevea Brasiliensis Muell Arg . ) At Some Storage Period. Jurnal Produksi Tanaman, 5(3), pp.484-492.

Hartawan, R. And Nengsih, Y., 2012. Kadar Air Dan Karbohidrat Berperan Penting Dalam Mempertahankan Kualitas Benih Karet Rudi. Agrovigor, 5(2), pp.103-112.

Heydecker, W., 1972. Vigour In Viability Of Seeds. , Pp.210-246.

Husni, M., Charloq And Siagian, B., 2014. Uji Pemberian Peg 6000 Terhadap Morfologi Benih Karet (Hevea Brassiliensis, muell-Arg.) Tanpa Cangkang Setelah Penyimpanan Giving. Jurnal Online Agroekoteknologi ., 2(2), pp.440 446.

Mudiana, 2007. Perkecambahan Syzygium Cumini (L.). , 8(1), Pp.39-42.

Parimala, K., Subramanian, K., Mahalinga Kannan, K. And Vijayalakhsmi, 2013. Seed Storage Techniques -A Primer, Pm Digital Products'konar Maligai', Chennai.

Prawiranata, W.S., Harran And P. Tdjandronegoro, 1981. Dasar dasar Fisiologi Tumbuhan Ii. In: Fakultas Pertanian IPB, Bogor.

Putra, G.P., Charloq And Ginting, J., 2013. Respons Morfologi Benih Karet (Hevea Brasiliensis Muell Arg.) Tanpa Cangkang Terhadap Pemberianpeg $6000 \quad$ Dalam
Penyimpanan Pada Dua Masa Pengeringan. Jurnal Online Agroekoteknologi Issn, 2(1), pp.145152. Available At: File:///F:/Ali/Payanname/Article/و

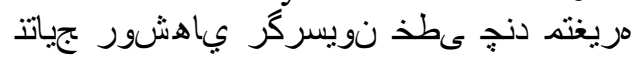

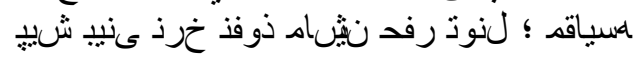

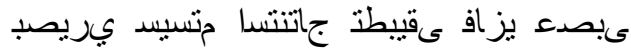
نيسد دمحم ، 2 يزير.Pdf.

Rahardjo, P., 2012. Pengaruh Pemberian Abu Sekam Padi Sebagai Bahan Desikan Pada Penyimpanan Benih Terhadap Daya Tumbuh Dan Pertumbuhan Bibit Kakao (The Effects Of Rice Husk Ash As Desiccation Material of Seed Storage On Viability And Cocoa Seedling Growth). Pelita Perkebunan (A Coffee And Cocoa Research Journal), 28(2), pp.91-99.

Sadjad, S., 1994. Metode Uji Langsung Viabilitas Benih, Ipb, Bogor.

Sitompul, S.M. And Guritno, B., 1995. Analisis Pertumbuhan Tanaman, Ugm Press, Yogyakarta.

Sutopo, L., 2002. Teknologi Benih, Rajawali Press, Jakarta.

Walters, C., N.W Pammeter, P. Berjak And J. Crane, 2001. Desication Damage, Accelerated Ageing And Respiration In Desiccation Tplerant And Sensitive Seeds. In: Seed Science Research, pp. 135-148.

Yazid, A., 2020. Viabilitas Benih Karet Pada Beberapa Media Simpan Dengan Lama Penyimpanan Yang Berbeda. Agrium, 22(3), Pp.137141. 